\title{
The Portrait of Pinguicula inVoluta Ruiz \& Pavon In the "Flora PeruViana": A Botanic DeteCtive StORY
}

\author{
S. Jost CASPER - Waldpark Seniorenheim - Prellerstr. 16 - D 01309 Dresden • Germany \\ - jost.casper@arcor.de \\ FrANK HELLWIG • Friedrich-Schiller-Universität Jena • Institut für Spezielle Botanik • Philosophenweg \\ $16 \cdot \mathrm{D}-07734$ Jena $\bullet$ Germany
}

On March 31, 1788, the pharmacognost and botanist Hipólito Ruiz López (Hipólito Ruiz), the pharmacognost Antonio Pavón Jimenez, and the draftsman Isidro Gálvez Gallo returned to Spain after an approximately ten-year long expedition (1777-1788) to the Viceroyalty of Péru. The plant hunters of the team had been very successful: they collected about 3,000 specimens of plants and made about 3,000 life-sized colored botanical illustrations. Of these, 2,230 survived and are preserved in the Archives of the Royal Botanical Garden of Madrid. They described about 150 new genera and 500 new species. In 1798, the first volume of the "Flora Peruviana, et Chilensis... et icones..." together with their "Systema vegetabilium..." were published. These volumes were preceeded by the 1794 edition of the "Florae peruvianae, et chilensis ...prodromus...". The travel itself was described in detail by Hipólito Ruiz et al. $(1940)^{1}$.

Pinguicula involuta (Front Cover), our subject of desire, was described in the "Flora Peruviana et Chilensis..." (Ruiz \& Pavón 1798a, 1: 20) and in their "Systema vegetabilium..." (Ruiz \& Pavón 1798b: 136). The diagnosis runs, identically in both publications, as follows: "P[inguicula]. nectario conico longitudine petali, scapo unifloro villoso, foliis ovatis, marginibus involutis."

The feature "rosette leaves ovate with margins rolled inwards" was the crucial factor for naming and binding of the nomen specificum involuta. However, initially another epithet was preferred. From the "Travels..." (Ruiz et al. 1940: 42) we learn that, on May 26, 1779, the collectors began their excursions and journeys "...through the montañas of Huasahuasi [sic!] and Palca..." of the province Tarma, and continued them “...to the April $24^{\text {th }}, 1780 \ldots$ During this time, we discovered a considerable number of trees, shrubs, grasses and herbs... all of which will be described extensively in the Flora of Peru, and I restrict myself here to indicating their generic and trivial names..." In the list of the plants, we read on page 45 "Pinguicula stellata" without any additional remark.

In chapter XLVIII (Ruiz et al. 1940: 229) it runs (with reference to the activities in 1787): "During our excursions through the montañas of Pillao and Chacahuasi I gathered and put in press a great number of plants, of which some were sketched, and I described the following."

Finally, in their "Flora..." as well in their "Systema vegetabilium..." Ruiz \& Pavón substituted the epithet "stellata" by "involuta" based on the feature "foliis ovatis marginibus involutis". Apart from this feature, $P$. involuta is distinguished by the corolla upper-lip lobes much shorter than the lower-lip ones and by the relatively long (about as long as the corolla lobes), slender, and cylindric but slightly curved spur.

The new Pinguicula species is illustrated nearly life-sized in color on lamina XXXI, fig. c (see Fig. 1 left). Four taxa are illustrated on this plate: a Calceolaria virgata, b Utricularia unifolia, $c$ Pinguicula involuta, $d$ Utricularia aphylla. This fact alone indicates that the painting is a combina-

1 The report of the excursions by Ruiz entitled "Relación del viaje hecho a los reynos del Perú y Chile..." prepared from his journals and completed for publication in 1793, remained unpublished in his lifetime. In 1931 it was published in Madrid. We studied the edition of 1940 in Dahlgren's English translation. 

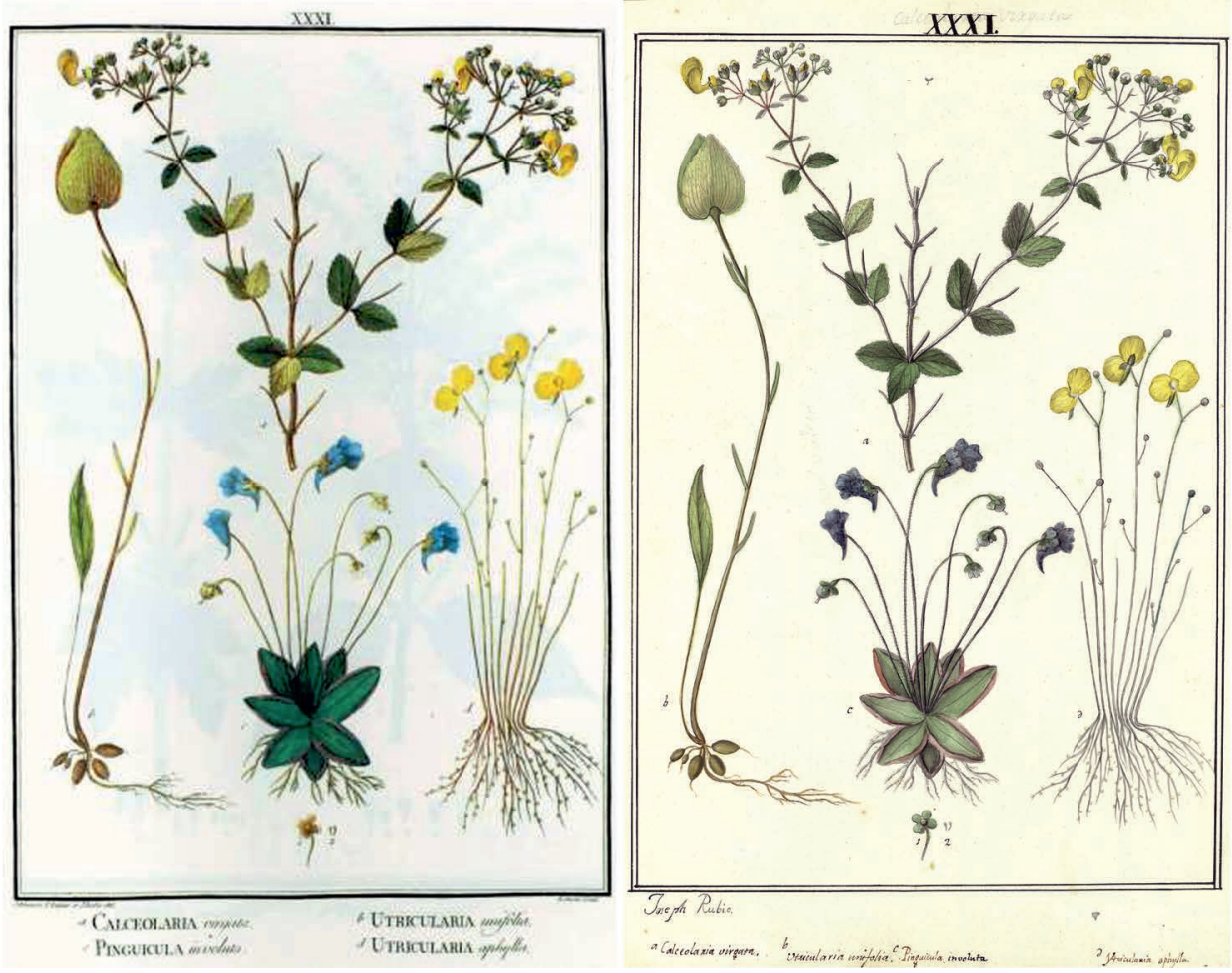

Figure 1: Left: Photocopy of the printed plate from Ruiz \& Pavón (1798a) Flora Peruviana... 1: Lam. XXXI with the watercolor portrait of Pinguicula involuta. Right: Photocopy of the original drawing of Joseph Rubio (signature on the bottom left-hand outside the frame) from Archivo del Real Jardin Botánico (CSIC: AJB04-D-0066_00), Madrid. Div. IV. Photocopy reproduced with permission.

tion based on various patterns. ${ }^{2}$ The portrait is attributed to the draftsmen J. Brunete ${ }^{3}, \mathrm{~F}$. Pulgar ${ }^{4}$, and $\mathrm{J}_{\text {. Rubio }}{ }^{5}$ as the signatures on the bottom left-hand outside the frame shows. The engraver of this illustration included their signature ("P. Suria") at the bottom right corner, outside the frame.

Who of the named three artists painted our Pinguicula? Is the fine portrait a true-to-life illustration?

From the "original" drawing preserved in the Archivo del Real Jardin Botánico Madrid (CSIC: AJB04-D-0066_00; see Fig. 1 right) it seems to be evident, that Joseph Rubio painted the entire plate XXXI. He added the names of the plants on the bottom outside the frame, too. (The engraver is not signed). J. Rubio had joined the Flora Peruviana team at Madrid in 1792. As he had never been in Peru, his drawings relied upon information given by the members of the expedition, the collected specimens, and the original drawings made on the spot, which are now housed at Madrid.

\footnotetext{
2 José Brunete drew Utricularia bifida (= Utricularia aphylla (lam. XXXI, fig. d). Whether he also drew Utricularia unifolia (lam. XXXI, fig. b), we could not find out. Besides Pinguicula involuta, J. Rubio drew Calceolaria virgata (lam. XXXI, fig. a). 3 José Brunete was the "first draftsman" of the expedition. He did not return to Spain. He died in Pasco in 1787 (Pupulin 2012). ${ }^{4}$ In May 1784, Francisco Pulgar (together with the botanist Juan José Tafalla Navascués, who replaced J. Dombey who had left the group four weeks before.) joined the expedition team in Peru and remained there until he died in 1815 .

5 In July 1792, Joseph Rubio was nominated director of engraving of the Flora Peruana by the "Junta de la Flora" and, in November 1793, as draftsman.
} 


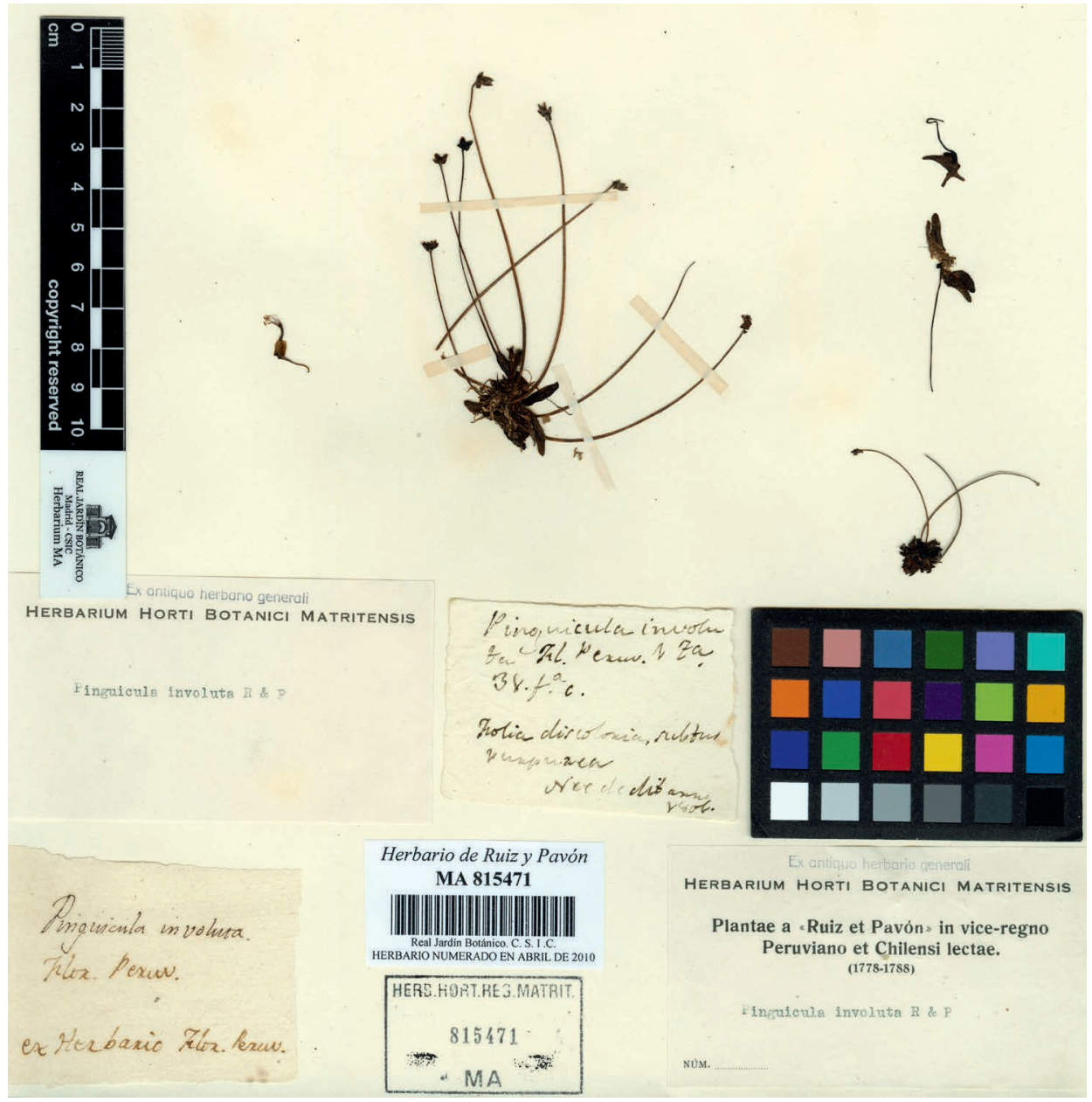

Figure 2: Pinguicula involuta, lectotype MA 815471. In the plate center the unusual specimen(s) with eight long stalks, some fruitless. This is presumably the source material for Rubio's drawing. Photocopy reproduced with permission

Following Dominguez et al. (2017:185) it is likely that as J. Rubio prepared the painting of Pinguicula involuta (Ruiz \& Pavón 1798a: lam. XXXI, fig. c), he had in his hands the specimens of MA 815471 . This specimen is unusual because of the large number of scapes developed on a presumably solitary Pinguicula rosette (see Fig. 2). This specimen bears eight leafless scapes curving upwards, none with flowers and fruits, but with seven retaining calyces. J. Rubio's drawing shows also eight scapes, four flowering and four fruiting, the latter shorter than the flowering ones (see Fig. 1). Apparently during the making of the plate, the draftsman supplemented the specimen with flowers and fruits missing on the voucher. He might have used the single flower that is conserved on specimen MA 815471 as his model, however, did he do so? In spite of the apparent similarity of the drawing to the specimen on MA 815471 some problems remain. First, the flowers are drawn too beautifully, and do not correspond with preserved specimens. Second, the spurs are drawn sickle-shaped, unlike 
the slender-cylindric ones in nature. Finally, the leaf rosette is drawn too schematically and does not compare well with the dried specimen. Apparently, it is unclear whether the illustration is based upon one or several specimens.

Does the Rubio-drawing reproduce the real character of the taxon in question? The generative parts (i.e. flowers and fruits) are the product of fantasy. A true-to-life illustration would have shown extremely short stalks with overhanging flowers overtopped by mature fruiting stalks. (As a rule, the fruiting scapes of Pinguicula are longer than the flowering ones and are not pendent.) The vegetative part, i.e. the leaf rosette, is drawn as a regular star with eight oblong (instead of ovate, as described in the protologue) leaves whose margins are hardly curled up. Rubio's portrayal (as seen in Fig. 1) is a diagram rather than a realistic illustration. $\mathrm{Ru}-$ bio's illustration is an idealization of a plant he never saw in life.

Surprisingly, such a true-to-life illustration of Pinguicula involuta exists!

The portrait, housed in the Archivo del Real Jardin Botánico (CSIC), Madrid, shows a dense cluster of green leaf rosettes forming a kind of cushion consisting of seven flowering and five budding plants (see Fig. 3). The very short (10-20 mm long) scapes bear blue flowers about 9-12 mm long. Fruiting

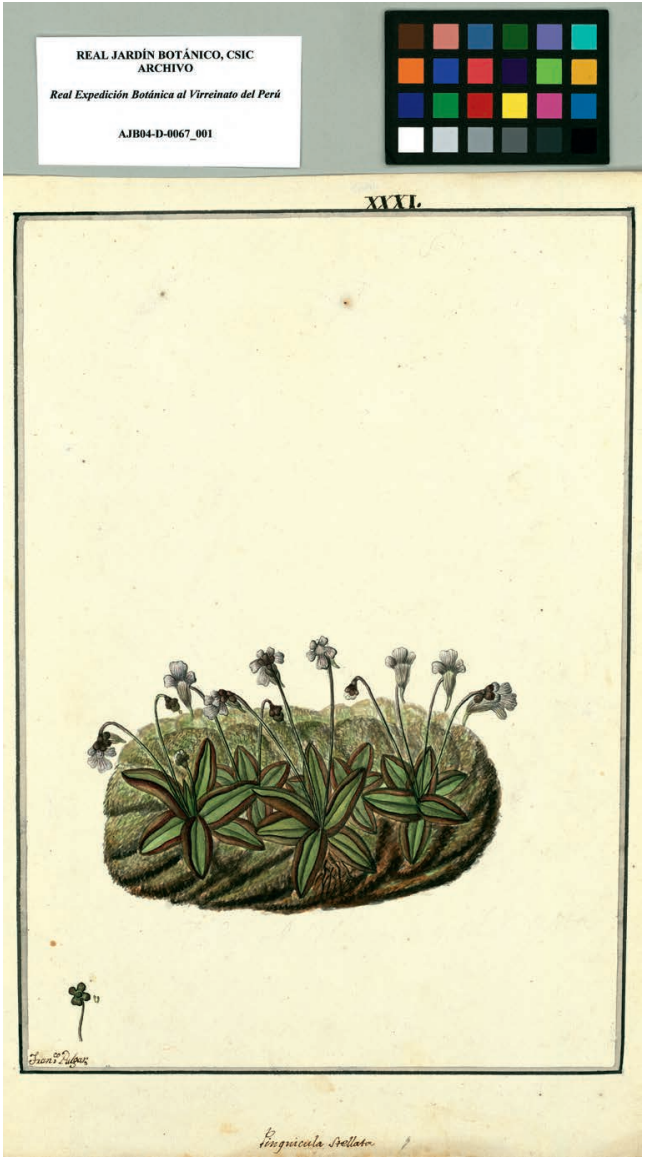

Figure 3: Pinguicula stellata. Photocopy of Francisco Pulgar's drawing. Archivo del Real Jardin Botánica (CSIC), Madrid. Div. IV. Photocopy reproduced with permission. specimens are not drawn. The leaf rosettes are star-like ("stellate"), the leaves are oblong with margins curled up. Below and to the left of the main picture is a single, isolated stalked open flower calyx. The plate is numbered XXXI, the portrait is signed by Fran. ${ }^{\text {co }}$ Pulgar (inside the frame left-hand at the bottom), and is named "Pinguicula stellata", on the bottom outside the frame.

From the artist's name F. Pulgar and the epithet stellata it is evident that the portrait was made in Peru during the expeditions to Panao and Chucahasi, which occurred after May $1784^{6}$, after the devastating fire in Macora in 1785. Most probably it was made in 1787 (Ruiz et al. 1940: 229230). Pulgar didn't draw "on-the spot” however; he probably worked with fresh flowering material brought to him by the botanists. ${ }^{7}$ Together with their information, he designed a picture that is almost life-like as comparison with modern photographs of the taxon in question shows (see Figs. 4 \& 5). The epithet "stellata", known to us otherwise but from Ruiz' journal of travels (1940: 45, 230),

\footnotetext{
${ }^{6}$ Cf. footnote 4 .

7 As noted in Puig-Samper (2012): "Our artists... work... without leaving to go to the field or forest and without the hikes the botanists do..."
} 
is an additional argument for the assumption of the Peruvian origin of the Pulgar plate.

During the making of the first volume of the Flora Peruviana, the Pulgar portrait and the epithet stellata "disappeared". After its return to Madrid in 1788, the expedition team immediately started its work in preparing Prodromus, Systema vegetabilium, and Flora of Peru and Chile, which were produced 1798 and the following years. Ruiz examined the material collected - especially checking the vouchers and paintings - made detailed descriptions of the collected plants (and animals), and arranged the illustrations for printing. After November 1793, José Rubio was responsible for making a great part of the plates of vol. 1 of the Flora Peruviana -77 plates were attributed to him. Apparently, Rubio was prompted by Ruiz(?) ${ }^{8}$ to combine the available paintings, vouchers, and descriptions of Pinguicula stellata to draw a picture of a single specimen representing the new species. In the process, its name was changed into Pinguicula involuta ${ }^{9}$.

Many questions remain regarding the production of Rubio's illustrations. We believe that Rubio had in his hands the painting of Pulgar - otherwise how does he know the shape and color of the flowers? But why did he present a specimen with both flowers and fruits, as he had never seen living or

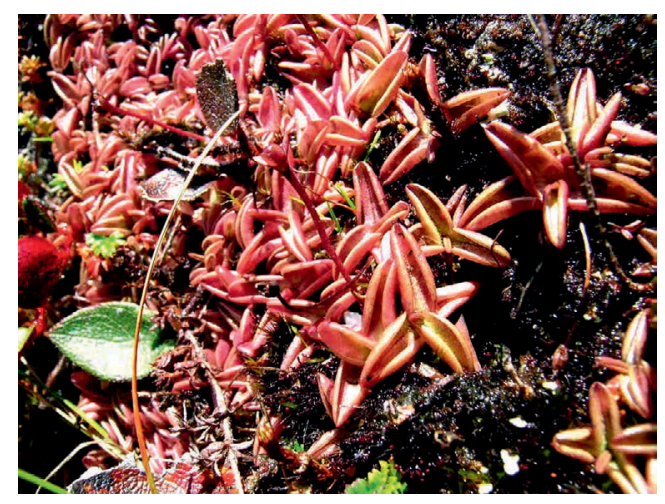

Figure 4: Pinguicula involuta. Inca Trail Peru. Cluster of star-like leaf rosettes. A single elongated and erect fruiting scape (center) is visible. Apart from the fruiting scape, such a living individual could have been the pattern of Pulgar's portrait of Pinguicula stellata. Photograph: F. Rivadavia, with permission.
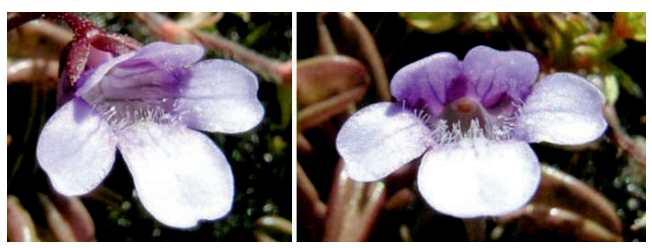

Figure 5: Pinguicula involuta. Inca trail Peru. Short-stalked flower in midst of a dense cluster of star-like leaves (its margins heavily curled up). Photograph: F. Rivadavia, with permission. dried specimens? Had he been instructed by the botanists?

Rubio's isolated single specimen of plate XXXI is not the product of true-to-life drawing, it is the result of combination of various sources available to him. But is it mainly the result of elaboration on his part? Or is it the result of the addition of elements (perhaps imagined) by a number of artists and botanists? ${ }^{10}$ It may be that Ruiz favored the final single-specimen-version against the original cluster-version to bring the picture in line with the other plant portraits of the Flora Peruviana.

\footnotetext{
${ }^{8}$ In the first half of 1794, the "Prodromus" was finished and the expedition members could prepare the descriptions and drawings for the first volumes of the Flora Peruana. Originally, I. Galvez, the first draftsman of the expedition, had to complete and perfect the drawings before handing them over to the engravers. We could not determine how deeply the real Jardín Botánico senior professor C. Gómez Ortega was involved in the preparation of the Flora Peruana. He ended his participation in his Flora Peruana activities at the end of May 1794. The description of the new species of the genera already known to science was performed between 1795 and 1804 (cf. Rodríguez Nozal 2007).

9 This is not the only case where a field (working) Pinguicula name was changed-Bonpland replaced Pinguicula loxensis with Pinguicula calyptrata and Pinguicula Mexicana by Pinguicula moranensis (Casper 2003).

${ }^{10}$ This is a clear violation of the official "instructions to the artists" given to J. Brunete and I. Galvez at the beginning of the expedition, that was to strictly copy nature in their production without adding elements of imagination.
} 
Our study has shown that the printed portrait of Pinguicula involuta in Ruiz-Pavón's Flora Peruviana (1798a, Vol. 1, lam. XXXI, fig. c), has been drawn by Joseph Rubio. The artist made the illustration in Madrid after 1793, based upon the descriptions from botanists (apparently Hippolito Ruiz), the preserved dried specimens of the plants (probably collected 1787 between Panao and Chacahuasi in Peru), and the original color drawing of a cluster of a blue flowering Pinguicula made by Francisco Pulgar in Peru (initially named Pinguicula stellata by Ruiz).

Rubio's portrait does not represent a true-to-life illustration of the specimen. It differs from reality by the following features:

1. The characteristic dense cluster-like growth has been given up in favor of an (allegedly) isolated growth of a single specimen.

2. The leaves of the rosette lack the heavily curled up margins.

3. Short overhanging fruiting stalks and overtopping flowering stalks rise from the leaf rosette. In reality, the relation of length between flowering and fruiting stalks is quite different; the fruiting flower stalks are erect (never overhanging), and distinctly overtop the flowering ones.

The Rubio portrait of Pinguicula involuta, and - to a certain degree- the original description in the Flora Peruviana can no longer been assessed as accurate. A modern concept of the taxon has to consider the Pulgar drawing and, naturally, the actual findings from recent collections.

\section{References}

Casper, S.J. 2003. Pinguicula loxensis (Lentibulariaceae) - a lost name by Humboldt and Bonpland? Carnivorous Plant Newsletter 32(1): 14-19.

Domínguez, Y., Panfet-Valdés, C.M., and Oliveiro Miranda, V.F. 2017. Typification of names in the genus Pinguicula L. (Lentibulariaceae). Phytotaxa 312(2): 179-198.

Puig-Samper, M.A. 2012. Illustrators of the New World. The Image in the Spanish Scientific Expeditions of the Enlightenment. Culture \& History Digital Journal 1(2): m102. http://dx.doi. org/10.3989/chdj.2012.m102.

Pupulin, F. 2012. The Orchidaceae of Ruiz \& Pavón's "Flora Peruviana et Chilensis". A taxonomic study. I. Anal. Jard. Bot. Madrid 69(1): 21-79.

Rodríguez Nozal, R. 2007. El trabajo científico en la España ilustrada: La Oficina Botánica y la publicación de las Floras americanas. Centre Recherches Latino-Américaines (URA C.N.R.S. 2007). Univ. Poitiers (Francia).

Ruiz, H., and Pavón, J. 1794. Florae peruvianae, et chilensis prodromus, sive novorum generum plantarum peruvianarum, et chilensium descriptiones, et icones. [I-III], I-XXII, 1-153 [154] pp., lam. 1-37. Madrid.

Ruiz, H., and Pavón, J. 1798a. Flora peruviana, et chilensis, sive descriptiones, et icones plantarum peruvianarum, et chilensium, secundum systema linneanum digestae, cum characteribus plurium generum evulgatorum reformatis. 1: [I-II] 1-78 pp., lam. 1-106. Madrid. [Pinguicula p. 20]

Ruiz, H., and Pavón, J. 1798b. Systema vegetabilium florae Peruvianae et Chilensis: characteres prodromi genericos differentias .... [Madrid?]: Typis Gabrielis de Sancha. 455 p.

Ruiz, H., Barreiro, A.J., and Dahlgren, B.E. 1940. Travels of Ruiz, Pavón, and Dombey in Peru and Chile (1777-1788). With an epilogue and official documents added by A.J. Barreiro. Translation by B.E. Dahlgren (Ed.). Public. (Field Mus. Nat. Hist. Bot.: 1909) 467. Bot. Ser. 21: 1-372. 


\section{CARNIVOROUS PLANT NEWSLETTER}

Journal of the International Carnivorous Plant Society

Volume 48, No. 3

September 2019

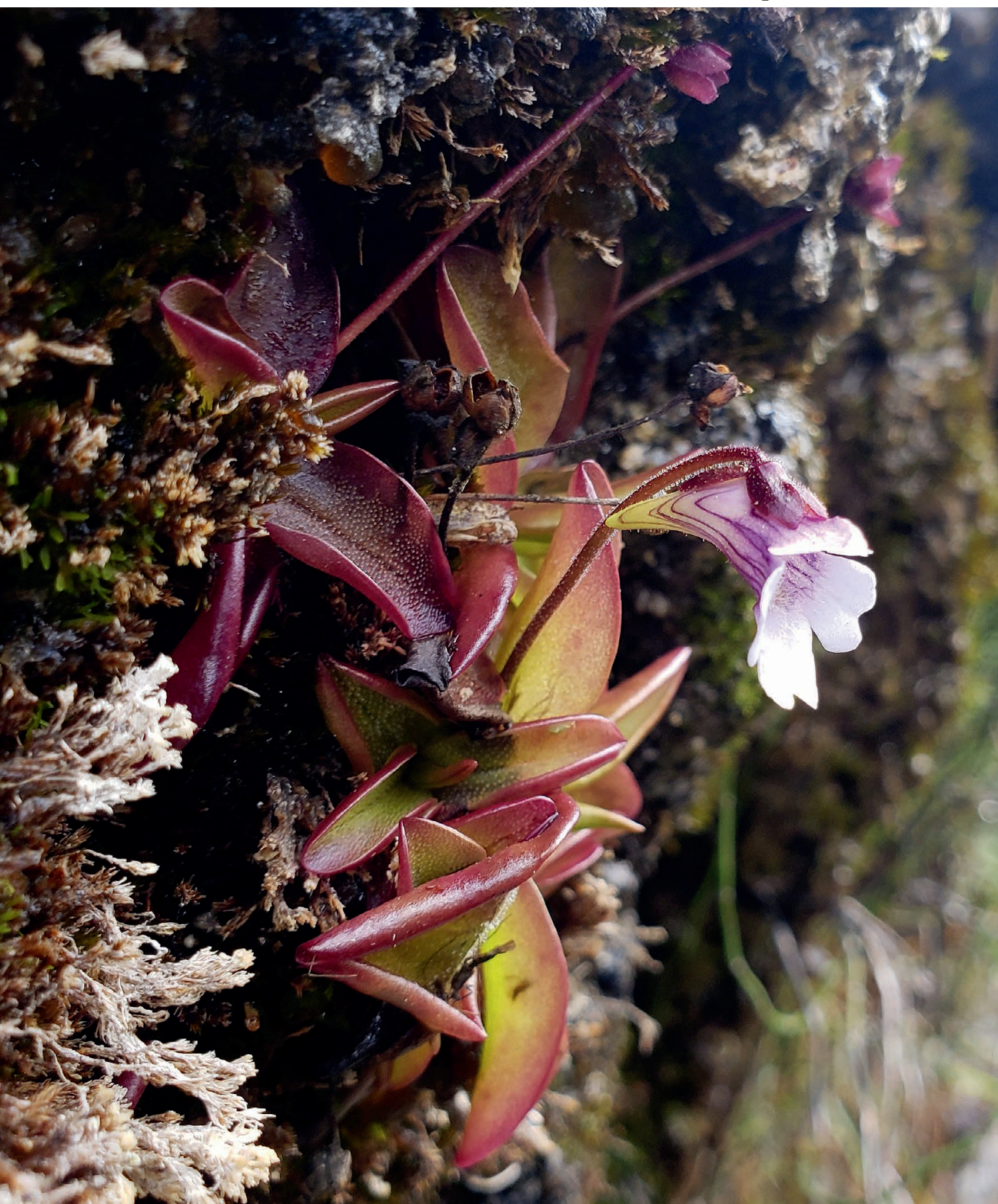




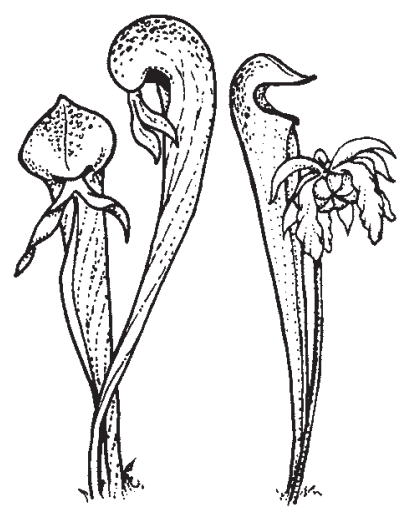

\section{CARNIVOROUS \\ PLANT \\ NEWSLETTER}

Journal of the International

Carnivorous Plant Society

www.carnivorousplants.org

\section{Volume 48, Number 3 September 2019}

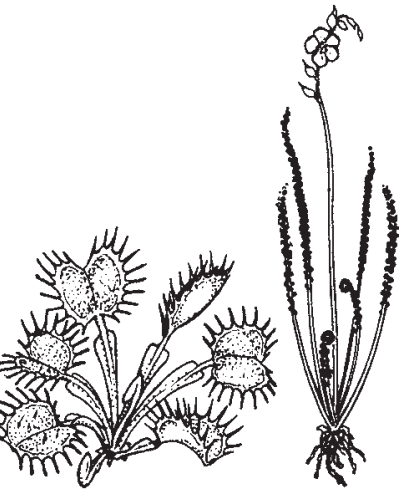

Front Cover: Pinguicula involuta growing on an east-facing vertical cliff dripping with water at $\mathbf{3 8 7 0} \mathrm{m}$ on the Andes Highlands near Cusco, southern Peru. Photo by Fernando Rivadavia. Article on page 122.

Back Cover: Drosera murfetii growing at the type location, Hartz Mountains, Tasmania. Photo by Richard Nunn. Article on page 128.

Carnivorous Plant Newsletter is dedicated to spreading knowledge and news related to carnivorous plants. Reader contributions are essential for this mission to be successful. Do not hesitate to contact the editors with information about your plants, conservation projects, field trips, or noteworthy events. Advertisers should contact the editors. Views expressed in this publication are those of the authors, not the editorial staff.

All correspondence regarding dues, address changes and missing issues should be sent to the Membership Coordinator at the ICPS. Do not send such correspondence to the editors. Checks for subscriptions should be made to the International Carnivorous Plant Society in US funds. Dues, including a subscription, are \$30 per year.
International Carnivorous Plant Society, Inc.
2121 N. California Blvd., Suite 290
Walnut Creek, CA 94596-7351, USA
icps@carnivorousplants.org

$\begin{array}{ll}\text { President } & \text { Richard Nunn, richardnunn@carnivorousplants.org } \\ \text { Vice President } & \text { John Brittnacher, john@carnivorousplants.org } \\ \text { Secretary } & \text { Cindy Slezak, cindy@carnivorousplants.org } \\ \text { Treasurer } & \text { Daniela Ribbecke, daniela@carnivorousplants.org } \\ \text { Board Member } & \text { Brent Jones, Conservation Director, brent@carnivorousplants.org } \\ \text { Board Member } & \text { Jan Schlauer, Cultivar Registrar, jan@carnivorousplants.org } \\ \text { Board Member } & \text { BobZiemer, bob@carnivorousplants.org } \\ \text { Membership Coordinator } & \text { Cindy Slezak, cindy@carnivorousplants.org } \\ \text { Webmaster } & \text { John Brittnacher, john@carnivorousplants.org } \\ \text { Media Coordinator } & \text { Chad Williams, chad@carnivorousplants.org } \\ \text { Seed Bank Manager } & \text { Joe Griffin, joe@carnivorousplants.org } \\ \text { CPN Editors } & \text { editor@carnivorousplants.org } \\ \text { Managing Editor } & \text { Bob Ziemer } \\ \text { Editor } & \text { Barry Rice } \\ \text { Editor } & \text { Karl Herold } \\ \text { Editor } & \text { John Brittnacher } \\ \text { Science Editor } & \text { Andreas Fleischmann } \\ \text { Science Editor } & \text { Fernando Rivadavia } \\ \text { Science Editor } & \text { Jan Schlauer }\end{array}$

Date of effective publication of the June 2019 issue of Carnivorous Plant Newsletter: May 9, 2019.

The ICPS is the International Cultivar Registration Authority (ICRA) for the names of cultivated carnivorous plants according to the International Code of Nomenclature for Cultivated Plants. Send relevant correspondence to the ICPS, Inc.

Carnivorous Plant Newsletter is published quarterly in March, June, September, and December by the ICPS, Inc., 2121 N. California Blvd., Suite 290, Walnut Creek, CA 94596, USA. Periodicals postage paid at Walnut Creek, CA and additional mailing offices. Postmaster: Send address changes to ICPS, Inc., 2121 N. California Blvd., Suite 290, Walnut Creek, CA 94596, USA. Printed by Allen Press, Inc., 810 E. 10th Street, Lawrence, KS 66044. Logo and masthead art: Paul Milauskas. (C) 2019 International Carnivorous Plant Society. All rights reserved. ISSN \#0190-9215 